\section{"A farmer's time is expensive": A qualitative study exploring the knowledge attitudes and perceptions of farmers regrading health and safety in Northern Ireland}

\author{
Aoife GIRVAN ${ }^{1}$, Graeme MITCHELL ${ }^{2 *}$
}

\begin{abstract}
The agricultural sector is important to Northern Ireland (NI) as it accounts for almost $10 \%$ of all jobs and $75 \%$ of all land usage. Despite a reduction in fatalities in other sectors, the number of fatalities in the agricultural sector in $\mathrm{NI}$ has remained stubbornly consistent. This research looked to use qualitative data to explore the knowledge, attitudes, perceptions and factors that influence health and safety measures and controls. Using a snowball sampling technique, a number of semi structure interviews were undertaken with participants to explore these areas. The findings of these semi-structured interviews identified six key themes: the importance of health and safety; the impact of poor health and safety; different generational attitudes; fear; time management and finance. This revealed that although participants feel they have some level of knowledge around health and safety, they felt this was lacking. However, a lack of knowledge did not mean they were unaware of the importance of health and safety and its potential impacts, although they perceived that farmers of a different generation to themselves were more at risk. Participants also indicated they were willing to make value judgements, where the need for action and cost of health and safety outweighs the importance implementing appropriate measures and control. Therefore, despite understanding the importance of health and safety, until the cost benefit equation is rebalanced for farmers in NI they still face significant risks to their health and safety.
\end{abstract}

Key words: farming; health and safety; barriers; fear; compliance; attitudes towards health and safety

\section{POVZETEK}

Kmetijski sektor je za Severno Irsko pomemben glede na to, da zagotavlja skoraj $10 \%$ vseh delovnih mest in obsega $75 \%$ celotne rabe zemljišč. Kljub zmanjšanju števila smrtnih žrtev $v$ drugih sektorjih, le-to $v$ kmetijskem sektorju Severne Irske ostaja nespremenjeno. $\mathrm{V}$ okviru raziskave smo se $\mathrm{z}$ uporabo kvalitativne metodologije osredotočili na znanje, stališča, dojemanje in druge dejavnike, ki vplivajo na izvajanje ukrepov za zagotavljanje varnosti in zdravja pri
Original scientific article

Received: 4. 12. 2020

Accepted: 30. 12. 2020

Published: 31. 12. 2020

${ }^{1}$ Public Health Institute, Faculty of Health, Education and Community, Liverpool John Moores University, $3^{\text {rd }}$ Floor Exchange Station, Tithebarn Street, Liverpool L2 2QP, UK

* Corresponding author

Mr Graeme Mitchell MCIEH CEnvH, Senior Lecturer, Public Health Institute, Faculty of Health, Education and Community, Liverpool John Moores University, $3^{\text {rd }}$ Floor Exchange Station, Tithebarn Street, Liverpool L2 2QP, UK E-mail: g.k.mitchell@ljmu.ac.uk

(c) 2020 Aoife Girvan, Graeme Mitchell. This is an open access article licenced under the Creative Commons Attribution NonCommercial-NoDerivs license as currently displayed on http:// creativecommons.org/licenses/by-nc$\mathrm{nd} / 4.0 \%$. 
delu. Udeleženci v raziskavi, s katerimi so bili opravljeni polstrukturirani intervjuji, so bili zajeti po metodi snežne kepe. Rezultati opravljenih intervjujev izpostavijo šest ključnih segmentov, in sicer: pomen varnosti in zdravja pri delu, posledice slabe varnosti in zdravja pri delu, različna stališča glede na generacijo, strah, upravljanje s časom in finance. Kljub temu, da udeleženci sicer menijo, da imajo določeno raven znanja o varnosti in zdravju pri delu, so mnenja, da ga še vedno nimajo dovolj. Slednje pa še ne pomeni, da se ne zavedajo, kako pomembna sta varnost in zdravje pri delu, čeprav so mnenja, da so kmetje bodočih generacij bolj ogroženi. Udeleženci so prav tako navedli, da so pripravljeni tehtati med potrebo po ukrepanju na področju varnosti in zdravja pri delu in stroški, ki zaradi tega nastanejo. Kljub zavedanju pomembnosti varnosti in zdravja pri delu se kmetje na Severnem Irskem še vedno soočajo z velikimi tveganji in bo tako tudi ostalo, dokler se enačba stroškov in koristi ne uravnoteži.

Ključne besede: kmetijstvo; varnost in zdravje; ovire; strah; skladnost; odnost do varnosti in zdravja

\section{INTRODUCTION}

The agriculture sector in the United Kingdom (UK) turns over more than $£ 4.5$ billion every year and is the cornerstone of Northern Ireland's (NI) economy. Throughout the UK, the agricultural sector supports one in eight jobs providing income for individuals, families and significantly enhancing the economy. [1]

Farming is the heart of many communities in NI with over 25,000 farm businesses, traditionally driven by family members for generations. In $\mathrm{NI}$ alone, farmers and farm workers account for 49,979 jobs $(9.9 \%$ of the workforce) and the total income from farming is £360 million. [2, 3] Approximately $75 \%$ of land in $\mathrm{NI}$ is used for agriculture, with eggs, dairy and meat being the largest sectors, accounting for over $80 \%$ of agricultural output, comparing with around 50\% for the UK average.

However, this sector is not without its dangers. During 2014 to 2018, the average number of fatalities within the agricultural sector in UK was 33. However, in 2019 this increased to 39 , six more than the 5-year annual average [4]. Although farming fatalities within $\mathrm{NI}$ showed a downward trend between 2012/13 and 2015/16 (11 fatalities down to 6 fatalities), they have stubbornly remained at this level and indeed have started to show a slight increase. This is in contrast to the overall workplace fatalities in $\mathrm{NI}$ which were down in 2018 by $31 \%$ from 16 in the previous year to 11. [5]

According to data obtained as a part of a 2015 survey of over 4,000 farmers an estimated 1,276 farm accidents requiring medical attention occurred in $\mathrm{NI}$ in the previous 12 months [6]. Following the farm accidents which required professional medical attention, $47 \%$ took no time off work, $35 \%$ undertook no farm work for $1-30$ days, $8 \%$ required $31-60$ days off and $10 \%$ required over 60 days off.

Yet farming continues to have a poor safety record and in $2017 / 18$, the Health and Safety Executive of Northern Ireland (HSENI) working in conjunction with local councils completed 7 successful prosecutions
Throughout the UK, the agricultural sector supports one in eight jobs providing income for individuals, families and significantly enhancing the economy. 
Farming is globally one of the most hazardous occupations, where farmers are injured at a rate four times greater than the average worker.

According to Gerrard, farmers face such high levels of health and safety risks because of long working hours, seasonal patterns of work, little or no supervision, use of machinery,

a lack of health and safety structure, chemicals and working in all types of weather. amounting to fines totalling $£ 173,750$, delivered 6,233 inspections and served 216 formal enforcement notices where poor practice was found.

The idea that farming poses a greater level of risk to those employed within it is nothing new. Elkind [7] argues that farming is globally one of the most hazardous occupations, where farmers are injured at a rate four times greater than the average worker.

In comparison to other industries, agriculture has an inbuilt set of characteristics resulting in many health and safety problems. According to Gerrard [8], farmers face such high levels of health and safety risks because of long working hours, seasonal patterns of work, little or no supervision, use of machinery, a lack of health and safety structure, chemicals and working in all types of weather. Evidence gathered by Solomon [9] suggests that accidental deaths among farmers is more common in the harvesting months of July, August and September. This could suggest that farmers become less safety conscious during these months or that throughout times of mounting pressure and stress to complete the harvest, their focus to stay safe if significantly impacted. It was also found that farmer's attitudes towards safety and risk taking behaviour were influenced by the belief that accidents are inevitable. In addition, the importance of profit [10] and the ineffective of health and safety education [11] also play their part. What does seem to drive compliance with health and safety requirements is fear - fear of being injured (or someone else being injured) and fear of losing their jobs or businesses as a result of an injury [12].

All of these factors contribute to fatalities and injuries within the agricultural sector, with the most common non-fatal accidents being due to poor manual handling and fatal accidents attributable to falls from height, machinery, vehicles and electrocution [4]. Therefore using a series of semi structured interviews, the aim of this study is to explore the knowledge, attitudes and perceptions that farmers have in regards to health and safety on their farms in Northern Ireland.

The objectives for the research are:

- To determine farmers' level of knowledge in regards to health and safety on the farm.

- To identify the attitudes of farmers regarding health and safety on the farm.

- To understand the perceptions of farmers regarding health and safety on the farm.

- To explore the factors which influence health and safety measures and controls on the farm.

\section{METHODS}

\section{Research Design}

In order to explore the knowledge, attitudes and perceptions fully, a qualitative design was chosen, with semi structured interviews undertaken with 7 participants who were above the age of 18 years and had previously or were currently working as a farmer, living in NI. 
A qualitative approach was believed to be more appropriate than quantitative approach. As it would provide the rich, contextual descriptions needed to analyse the data and achieve the aim and objectives. The knowledge, attitudes and perceptions of the participants are described verbally, in detail, in order to answer the research question. According to Tsai et al. [13] qualitative data is not about generalisability but creating insights about certain phenomena in greater depth and detail than is possible through quantitative designs. Qualitative research methods are valuable in providing rich descriptions of unique events and illuminating the experience and interpretation of the participants.

\section{Sampling}

A snowball sampling method was used to recruit participants to this study. According to Naderifar et al. [14] snowball sampling is a convenience sampling method and is applied when it is difficult to access participants with the target characteristics. In this method, the existing participants recruit future participants among their acquaintances and the sampling continues until data saturation.

It is believed people who chose to participate may only reflect a certain opinion, as they had to feel strongly enough to participate [15] However, due to the specific aim of the research and target population, this sampling method was deemed most appropriate. Cohen and Arieli [16] believe snowball sampling is a commonly used method to locate, access and involve participants from specific populations where the researcher anticipates difficulties in creating a representative sample. The farming population of Northern Ireland are mainly scattered across the countryside and distanced from towns or cities, making it difficult to access with ease.

\section{Data collection}

Data for this research was collected using a semi-structured interview with each participant. The use of this type of research tool allows for open-ended responses from the participants, which will generate more in depth information, whilst at the same time allowing the researcher to guide the conversation and keep the participants on tack. The questions for the semi-structure interview were generated by the authors for the purpose of this research and focused on the participants' knowledge, attitudes and perceptions of health and safety in farming in $\mathrm{NI}$, as well as those factors that may influence health and safety measures and controls. Prior to the collection of data, the semi-structured interview was piloted and amended as necessary.

The first two participants were contacted by telephone through mutual connections within the Northern Irish farming population and given an overview of the research study. These participants were made aware that participation was voluntary and asked to identify any other potential participants and to direct them to contact the researcher. Potential participants who made contact with the researcher were emailed a Participant Consent form and Participants Information sheet. Once they had agreed to take part in the research, they were asked to attend an interview at a mutually agreed, public location.
Data for this research was collected using a semistructured interview with each participant. The use of this type of research tool allows for open-ended responses from the participants, which will generate more in depth information, whilst at the same time allowing the researcher to guide the conversation and keep the participants on tack. 
The researcher conducted 3 interviews within a public library in County Tyrone, 2 interviews in a public library in County Derry and 2 interviews in a public library in County Armagh, all of which are located in NI. Each interview lasted approximately 20 minutes.

Prior to each interview the researcher gave a brief overview of the topics included in the interview and the purpose of the research study. The researcher also reinforced to each participant that they did not have to provide answers for any topics they wished not to discuss. Permission was requested from each participant to audio record the interview and advised that each person would remain anonymous through pseudonyms such as, 'Participant 1, Participant 2'. Field notes were also taken throughout the interviews to ensure the researcher could differentiate between participants' voices and record non-verbal activity when transcribing.

As this research was undertaken as part of the BSc (Hons) Environmental Health degree programme, prior to collection of any data, ethical approval was obtained from Liverpool John Moores University.

\section{Data Analysis}

After the completion of each interview, the data was transcribed verbatim and names were replaced with pseudonyms, with a code to identify the participant. According to Burnard et al [17] interview transcripts, field notes and observations provide a descriptive account for the study, but don't provide explanations. The transcripts needed to identify themes and ideas that emerge from the data. According to Saldana [18], coding enables the researcher to group similarly coded data into categories because they share some characteristic- the beginning of a pattern. Williams and Moser [19] suggest the best way to code is to read transcripts and field notes in order to fully understand the themes, phrases, and topics. The researcher colour coded potential themes and assessed them further to create a thematic pattern. The data was then coded by analysing the transcripts and grouping codes of similar meaning into categories. These categories were then analysed to look for themes and relationships between them. The main findings and analysis of the data is presented in the results section, identifying the key themes and utilising verbatim quotes as supporting evidence.

\section{RESULTS AND DISCUSSION}

From the semi-structured interviews, the following key themes were identified:

Theme 1: The importance of health and safety on the farm

Theme 2: The impact of poor health and safety

Theme 3: Generational Attitudes

Theme 4: Fear

Theme 5: Time Management

Theme 6: Finance 


\section{Theme 1: The importance of health and safety on the farm}

There was an acknowledgement across all participants that health and safety is an important issue when working in farming:

'That it's important and something that needs to be taken very seriously.' (Participant 5)

'I think of it every day. It's so important, think of all the people who have died because of not taking enough care.' (Participant 7)

Yet despite this acknowledgement, there is an acceptance that it is not always a priority for farmers:

'It's important, but probably something that is overlooked a lot of the time.' (Participant 1).

\section{Theme 2: The impact of poor health and safety}

Several participants considered the impact on themselves, if there was poor health and safety practice on the farm:

'It's a matter of life and death, anything could go wrong on a farm in the blink of an eye. It involves so many fatalities, staying vigilant is the most important thing.' (Participant 4).

However, awareness of the impacts extended beyond just the effects on the individual but on their businesses as well particularly if an enforcement body was to inspect:

'I would get a non-compliance and it needs to be rectified straight away or else. I will lose my status as free-range and won't be allowed to supply in certain supermarkets.' (Participant 6).

Many of the participants were concerned of not meeting the requirements for their insurance policies and being held reliable for accidents on the farm, significantly impacting their businesses:

'In the event of an accident you might not be insured if you haven't followed the legislation and if you were being neglectful.' (Participant 2).

'If you did have an accident and the farm wasn't up to date, the insurance would come out and do an assessment and not pay out for anything. They would tell you- you're reliable.' (Participant 1).

Indeed this awareness also extend to the impacts on the wider community as well:

'The consequences can be deadly as we know and take such a hold on a family and community' (Participant 1).

Participant 6 described the fatality of a young person who died due to poor health and safety on the farm as:

'Absolutely devastating. His poor family have never been the same since, he was only 19'.
'I would get a noncompliance and it needs to be rectified straight away or else. I will lose my status as free-range and won't be allowed to supply in certain supermarkets.'

'If you did have an accident and the farm wasn't up to date, the insurance would come out and do an assessment and not pay out for anything. They would tell you- you're reliable.' 
'When I started farming there was no focus on laws and regulations, there wasn't as much emphasis as there is

now.'

'Maybe if older people were better educated and informed, they would start to actually think about it. Farms and equipment have got

bigger since when they started farming, things have got faster, and yards have more electrics.'

\section{Theme 3: Generational Attitudes}

The data indicated a clear contrast of attitudes regarding farm health and safety between young and older participants:

'Younger people are better clued in.' (Participant 1).

When another participant was asked about health and safety on the farm they stated:

'The older generation don't know as much about it' (Participant 3).

Both statements were reinforced by an older participant who suggested:

'When I started farming there was no focus on laws and regulations, there wasn't as much emphasis as there is now.' (Participant 4).

Several participants contradicted these statements and felt that older people were at an advantage due to having more experience on the farm. Participant 2 explained that younger people did not hold the experience of an older farmer and therefore, were at greater risk on the farm:

'Inexperience is a massive danger as well. I feel like younger people are at more risk because they haven't got experience.'

Additionally, Participant 7 explained:

'That's why I think experience is so important because it doesn't cost anything to have experience and a wise head and to know how to keep yourself safe.'

It became clear throughout several interviews that younger people felt that they were at less risk on the farm than older people due to raised awareness of health and safety and mandatory training. The data suggested that some participants felt the older generation would suffer poor health and safety practices due to a lack of education:

'You have to do all your training and that now, where older people wouldn't necessarily have that.' (Participant 1).

'Maybe if older people were better educated and informed, they would start to actually think about it. Farms and equipment have got bigger since when they started farming, things have got faster, and yards have more electrics.' (Participant 6).

Some participants expressed a lack of health and safety awareness among the older generation and that older farmers had developed habits on the farm- perhaps not leading to the best safety practice:

'Older people don't know enough about it. They just do what they've always done because it wasn't a big thing 10-15 years ago. So, I think teaching older people needs to be addressed.' (Participant 1).

This was reinforced by another participant but felt that modernisation is causing farming to be of higher risk:

'A lot of farmers have bad habits, and, in my time, you just got on with it because we never knew any better. There wasn't as many dangers when the older generation started, machinery is way more modern now and in my opinion animals have got wilder.' (Participant 4). 
Another participant suggested that training courses were becoming more accessible online and that the younger generation would benefit from this more than the older:

'A lot of the training you can do online and at home, but older farmers wouldn't know that.' (Participant 5).

Some participants questioned their own attitudes towards health and safety on the farm feeling they should and didn't hold the required knowledge to obtain good health and safety practice:

'Truthfully, I only know the basics, not as much as I should.' (Participant 5).

Additionally, Participant 4 stated:

'Probably like most other people, not enough and not always making the right decisions.'

\section{Theme 4: Fear}

The interviews explored the participants' perceptions on the biggest risks and dangers on a farm and how health and safety impacted their daily lives as farmers. When exploring these topics, all participants portrayed a degree of fear concerning the repercussions of poor health and safety practice while on the farm. One of the main concerns highlighted by all participants was fear of injury:

'Nobody wants to be injured or god forbid die.' (Participant 2).

'The mask so I don't breathe in dust. They talk about farmers lung I don't want that.' (Participant 1).

I might not always worry about lights and maintenance of the machinery but definitely PTO shafts because they can cause bad accidents.' (Participant 3).

A number of participants indicated a fear of death and referred to 'near miss accidents' and the biggest risks on the farm that could cause this:

'You might be doing something and have a near miss and just think that could have been really serious. I've had a lot of close calls. It makes you really worried.' (Participant 4).

I have electrical checks done every year to make sure everything is working correctly, only checked by a certified electrician though, I don't know anything about that, I would get electrocuted.' (Participant 6).

'Equipment will break all the time, for tractors there is usually a PTO shaft and it needs to be protected otherwise it can grab clothing and kill people straight away.' (Participant 7).

Participant 1 stated:

'I just think, I don't want to die; it scares me.'

Several participants described the fear they felt after hearing about a farming related injury or fatality through the media or by word of mouth:
All participants portrayed a degree of fear concerning the repercussions of poor health and safety practice while on the farm. 
All participants referred to time management and the impacts it has while working on a farm. It was clear that all participants felt that time pressures and restraints were key to poor health and safety practice.
'I would think about it most when l've heard of a fatality or serious accident that I was lucky enough not to be involved in. You know when I hear them on the media or by ear, I just think wow that could happen to anyone. It gives you food for thought, you realise how risky the work is.' (Participant 2).

Additionally, Participant 7 described:

'Oh and the slurry I mentioned before, the gases are so dangerous, I'll never forget about that story of them three lads who died because of it.'

One participant highlighted the fear they felt after watching a television advertisement made to raise awareness of farm health and safety and the dangers on a farm:

'Them TV advertisements as well. There was one where a child got driven over because the father was in such a rush and didn't even look behind, so scary.' (Participant 5).

A number of participants conveyed fear when describing how poor health and safety could potentially destroy their businesses and create wider financial issues:

'If a loose wire came out, my whole business could go on fire.' (Participant 6).

Additionally, Participant 5 stated:

'They would shut you down, then what would you do if you couldn't make any money? You would lose your business.'

It was also highlighted that participants felt feared of not complying with regulations or policies of certain authorities and being held accountable in situations of poor health and safety practice on the farm:

'Probably if I had someone inspecting my farm more often, otherwise I would be in legal trouble.' (Participant 3).

'It would be a financial penalty to me if I didn't comply, which obviously I don't want.' (Participant 6).

\section{Theme 5: Time Management}

All participants referred to time management and the impacts it has while working on a farm. It was clear that all participants felt that time pressures and restraints were key to poor health and safety practice. Participant 4 stated that:

'Truthfully, if there is something that needs to be done quickly, I might not be as precautious as I should be.'

'If you're just in a massive rush and not looking or taking care, something bad is bound to happen.' (Participant 7).

A number of participants felt that in order to complete all of their daily tasks, they needed to work as quickly as they could and avoid timeconsumption: 
'A big thing on the farm is time-saving, so, sometimes cutting corners needs to be done but doesn't always lead to the best safety practice.' (Participant 1).

'You know, a farmer's time is expensive. If it takes them an extra hour, that's an hour where they're not making any money.' (Participant 6).

All participants suggested that feeling 'under pressure' has influence on time management and acknowledged that this would usually lead to poor health and safety practice on the farm:

'Someone maybe gets off a tractor in a hurry and fall or something, just time-keeping. Too much pressure involved with farming.' (Participant 2).

'Because it's quick, it's all about speed. Just needed to get the job done, but now he'll never work again.' (Participant 3).

"I was so under pressure as well. I had one million things to do and I saw that it needed fixed so I just thought I would get on with it.' (Participant 6).

Majority of participants found that assessments on machinery and wearing PPE was at times not practical because of the mounting pressures of keeping within a time frame:

'I might not always worry about lights and machinery, just might be too busy.' (Participant 2).

'Sometimes, in the haste of the moment and you're under pressure, it's hard to go by the book, it's about getting the job done.' (Participant 5).

\section{Theme 6: Finance}

All participants felt strongly about the expense of health and safety and some suggested that the cost of health and safety outweighed the benefit. Participant 6 stated that:

'Some farmers will say it's too expensive and I don't need that anyway.'

'Well, truly, farming requires a tight budget. You wouldn't invest in things that you don't really see a benefit in.' (Participant 2).

Majority of the participants felt that the expense of health and safety measures and controls on a farm were discouraging:

'Everything health and safety wise on a farm is expensive, it really discourages you from doing it, honestly.' (Participant 7).

'The money is a massive deterrent for practising health and safety, everything is expensive.' (Participant 1).

It was also suggested by some participants that the lack of health and safety enforcement on the farms was key for limited health and safety measures and controls:

'There aren't enough checks done for health and safety on the farms by health and safety bodies.' (Participant 4). 
The research identified that younger participants felt advanced technologies and the modernisation of farms gives them an advantage in employing effective health and safety measures over the older generation.

Overall, the participants had a positive attitude to health and safety and perceived the importance of health and safety on their farms.
'There should definitely be more farm health and safety checks, I haven't had any.' (Participant 6).

'There isn't any enforcement, nobody does anything about it over here.' (Participant 3).

Despite many participants feeling that expense and lack of enforcement being the main reason for poor health and safety measures and controls, several participants felt that their safety is more important. These participants spoke of the 'value of life' and that their safety outweighed the expense:

'Usually, health and safety aren't overly expensive when you think of the value of it and the value of your own life. You just can't put a price on life.' (Participant 2).

'It's a tough one, some farmers genuinely may not have the money to practice health and safety, but in my opinion, how do you put a price on a life?' (Participant 6).

This research looked to explore the knowledge, attitudes and perceptions of farmers regarding health and safety on the farm in $\mathrm{NI}$ and the factors that influenced health and safety measures and controls of the farm. These are now discussed in light of the six themes that were generated by the semi-structured interviews.

In terms of knowledge, participants felt that whilst they possessed some knowledge of health and safety, they felt that this was perhaps incomplete. However, there did not appear to be any particular desire to address this and participants did not express any plans to improve their own level of knowledge. This supports the ideas of Murphy et al. [11] that farm health and safety education in itself is not an effective measure to reduce injuries and fatalities on a farm. The influence farm safety education has on farmers continues to be questioned and there are beliefs that the real issue is with the farmers and whether they will practice the education they have learnt. Interestingly there did appear to a generational difference when looking at knowledge, with the each generation feeling that the other was lacking. The research identified that younger participants felt advanced technologies and the modernisation of farms gives them an advantage in employing effective health and safety measures over the older generation. Whereas, older participants believed that experience was key to maintaining good health and safety practice and avoiding farm accidents - older participants described how previous accidents or near accidents had improved their safety practice while working on the farm.

Overall, the participants had a positive attitude to health and safety and perceived the importance of health and safety on their farms. In line with Elkind [7] and Gerrard [8] they recognised the intrinsically risky nature of their business. The majority of participants reflected on times of 'near miss' accidents and injuries they sustained from poor health and safety practice. Some participants discussed feeling 'lucky' to not have been involved in a serious accident but spoke of injuries or fatal accident stories which impacted their attitudes of health and safety 
when working on the farm. This presented an element of acceptance with many of the participants that injuries on the farm were inevitable. This acceptance of the inevitability of accidents poses challenges for officers, who as well as enforcing legislation will look to change behaviour and develop more of a safety culture within farms.

In relation to the factors that influence health and safety measures and controls, perhaps the greatest driver requirements was fear, as established by Wilkins [12]. All participants of this study described a degree of fear regarding one or more elements of health and safety while working on the farm. The fear shared among participants was not only of injury or death but extended to the wider aspects of their businesses. Although many participants felt fear of injury or fatalities due to previous accidents and local or national accident stories, many were afraid of being held accountable for an accident and the financial consequences it could cause.

However, in contrast to this the participants identified issues that would prevent these measures and control being put in place. The majority of the participants discussed having a heavy workload every day and feeling pressure to complete all their work, ultimately making as much profit as possible or allowing the business to remain commercially viable. In many cases, the participants described completing a job on the farm as being more important than taking safety precautions due to time constraints and financial gain. This echoes what Durey and Lower [10] found where farmers considered profits more important than safety. It also echoes the sentiments of Solomon [9], where there are pinch points within the farming year when health and safety perhaps takes a back seat to the need to get the job done.

It is perhaps understandable that the participants believed that the expense of health and safety measures and controls act as a deterrent. Many described the cost as outweighing the benefit of health and safety measures and controls on the farm. However, there were several that considered their own safety as more important than the expense of health and safety equipment and practices. It was clear that many of the participants seemed to understand the principle of health and safety which is 'reasonably practicable'. However, they seemed to create their own 'cost benefit equations', but their view could certainly be different from that of an enforcing officer.

\section{CONCLUSION}

It is clear that farmers in $\mathrm{NI}$ are presented with daily challenges regarding physical health, financial stability and mental health stressors. It seems likely that health and safety on the farm in $\mathrm{NI}$ will continue to present issues throughout the future despite an understanding and acceptance of its importance by farmers.

All participants involved in this study expressed a lack of knowledge on health and safety and agricultural, which may be caused by a lack of health and safety enforcement within the farming community of NI.
All participants of this study described a degree of fear regarding one or more elements of health and safety while working on the farm. The fear shared among participants was not only of injury or death but extended to the wider aspects of their businesses.

All participants involved in this study expressed a lack of knowledge on health and safety and agricultural, which may be caused by a lack of health and safety enforcement within the farming community of NI. 
Despite this lack of knowledge, there was a strong sense of participants having a positive attitude towards health and safety and being able to perceive its importance - although this seems to stem mainly from participants own previous or near miss accidents and by hearing of an accident on another farm that involved a local person.

This fear appears as the main driver for implementing good health and safety practices on the farm. The level of fear felt by all participants extended from fear of injury or death (to themselves or others) to noncompliance. Many of the safety practices discussed were in place in order to comply with insurance policies or the wider companies who employed the participants. This sense of fear was felt by majority of participants who were concerned of receiving financial penalties for poor health and safety practice or ultimately, losing their businesses and livelihoods.

However, great as this level of fear appears to be, it is dwarfed by the need to make the business financially viable and farmers are willing to compromise on health and safety standards in order to achieve this. This many participants felt that the time pressures to "get the job done" were the root cause of this.

Therefore, it is apparent that many farmers in $\mathrm{NI}$ are still at risk and will continue to be so until the cost/benefit equation is rebalanced. This could be achieved by looking to increasing knowledge and providing potential financial incentives for farmers.

\section{REFERENCES}

[1] Ulster Farmers' Union (2017) Farming in Northern Ireland [online] Available at: https://www.ufuni.org/farming [Accessed 18th October 2019]

[2] Allen, M. (2016) Northern Ireland's agri-food sector - background and possible 'Brexit' considerations [online]

Availableat: http://www.niassembly.gov.uk/globalassets/documents/raise/ publications/2016-2021/2016/aera/6616.pdf [Accessed 20th November 2019]

[3] National Farmers Union (2017) Contribution of UK Agriculture [online] Available at: https://www.nfuonline.com/nfu-online/news/report-21117contributions-of-uk-agriculture/ [Accessed 18th October 2019]

[4] Health and Safety Executive (2019) Fatal injuries in agriculture, forestry and fishing in Great Britain 2018/19 [online] Available at: http://www. hse.gov.uk/agriculture/pdf/agriculture-fatal-injuries-1819.pdf [Accessed 28th October 2019]

[5] Health and Safety Executive Northern Ireland (2018) Decrease of 31\% in workplace deaths but number of serious injuries up $27 \%$ [online]

Available at: https://www.hseni.gov.uk/news/decrease-31-workplacedeaths-number-serious-injuries-27-0 [Accessed 20th November 2019]

[6] Health and Safety Executive Northern Ireland (2017) HSENI reports increase in workplace deaths but number of serious injuries down by $13 \%$ [online]

Available: https://www.hseni.gov.uk/news/hseni-reports-increaseworkplace-deaths-number-serious-injuries-down-by-13 [Accessed 22nd October 2019]

[7] Elkind, P. (1993) Correspondence between knowledge, attitudes, and behavior in farm health and safety practices. Journal of Safety Research [online] 
Available: https://www.sciencedirect.com/science/article/pii/ 002243759390028L\#! [Accessed 21st November 2019]

[8] Gerrard, C. (1998) Farmers' occupational health: cause for concern, cause for action. Journal of advanced nursing, 28(1), pp.155-163 [online]

Available: https://onlinelibrary.wiley.com/doi/full/10.1046/j.1365-2648. 1998.00748.x[Accessed 22nd October 2019]

[9] Solomon, C. (2002) Accidental injuries in agriculture in the UK. Occupational medicine, 52(8), pp.461-466 [online] Available at: https://academic.oup.com/occmed/article/52/8/461/1404439 [Accessed 21st October 2019]

[10] Durey, A. \& Lower, T. (2014) The Culture of Safety on Australian Farms. Rural Society, 14(1), pp.57-69 [online] Available: https://www.tandfonline.com/doi/abs/10.5172/rsj.351.14.1.57?casa_token=gLN2Zwe26psAAAAA:CqFj8wvazwf1Ss6VmRkIRepvLPjJrj26xlg9sssh2rac2 Zv6kjwd46ilDfr2ERzheFqz3yMjvZ3t [Accessed 3rd January 2020]

[11] Murphy, D., Kiernan, N. \& Chapman, L. (1996) An occupational health and safety intervention research agenda for production agriculture: Does safety education work? American Journal of Industrial Science. 29(4), pp.392-396 [online]

Available: https://www.ncbi.nlm.nih.gov/pubmed/8728146 [Accessed 3rd January 2020]

[12] Wilkins, J. (2011) Construction workers' perceptions of health and safety training programmes. Construction Management and Economics. 29(10), pp.1017-1026 [online]

Available: https://www.tandfonline.com/doi/abs/10.1080/01446193.20 11.633538[Accessed 3rd January 2020]

[13] Tsai, A., Kohrt, B., Matthews, L., Betancourt, T., Lee, J., Papachristos, A., Weiser, S. \& Dworkin, S. (2016) Promises and pitfalls of data sharing in qualitative research. Social Science and Medicine, 169(1), pp.191198 [online]

Available: https://www.ncbi.nlm.nih.gov/pubmed/27535900[Accessed 16th January 2020]

[14] Naderifar, M., Goli, H. \& Ghaljaiee, F. (2017) Snowball Sampling: A Purposeful Method of Sampling in Qualitative Research. Strides in Development of Medical Education, 14(3) pp.1-3 [online]

Available: https://pdfs.semanticscholar.org/6aec/96da14bbc27c9707bc94a 5c42fc96a952571.pdf?.ga=2.262311621.874380835.1587911648434924764.1587911648 [Accessed 16th January 2020]

[15] O'Leary, Z. (2004) The essential guide to doing research. London: SAGE. pp.110

[16] Cohen, N. \& Arieli, T. (2011) Field research in conflict environments: Methodological challenges and snowball sampling. Journal of Peace Research, 48(4) pp.423-435 [online]

Available: https://journals.sagepub.com/doi/abs/10.1177/00223433114 05698[Accessed 20th January 2020]

[17] Burnard, P., Gill, P., Stewart, K., Treasure, E. \& Chadwick, B. (2008) Analysing and presenting qualitative data. British dental journal, 204(8), pp.429 [online]

Available: https://www.nature.com/articles/sj.bdj.2008.292 [Accessed 22nd January 2020]

[18] Saldaña, J. (2016) Goodall's verbal exchange coding: An overview and example. Qualitative Inquiry, 22(1), pp.36-39 [online]

Available: https://journals.sagepub.com/doi/pdf/10.1177/10778004156 03395[Accessed 22nd January 2020]

[19] Williams, M. \& Moser, T. (2019) The art of coding and thematic exploration in qualitative research. International Management Review, 15(1), pp. 45-55 [online]

Available: https://pdfs.semanticscholar.org/5dd2/51ddfbb6a563b900e 53a9b3476a8c4b2557b.pdf [Accessed 22nd January 2020] 